\title{
Association between Subjective Well-Being and Retirement among Older People
}

\section{Lia Pinheiro Freitas ${ }^{1}$, Maria Vieira de Lima Saintrain ${ }^{2}$, Sandy Kaena Soares de Freitas $^{3}$, Davi Oliveira Bizerril ${ }^{4}$, Edgar Gomes Marques Sampaio ${ }^{5}$}

${ }^{1}$ Nurse. Student of the Public Health Master Program of the University of Fortaleza - UNIFOR, Brazil

${ }^{* 2}$ DDS, Msc, PhD, Pos-doc in Public Health, Professor of the Public Health Masters Program, University of Fortaleza - UNIFOR, Brazil.

${ }^{3}$ Student of Dentistry Course - University of Fortaleza - UNIFOR, Brazil

${ }^{4}$ DDS, Msc. Student at the Public Health Doctorate Program UFC. Professor of Dentistry Course, University of Fortaleza - UNIFOR, Brazil

${ }^{5}$ Estatístico, Student of the Public Health Master Program of the University Federal do Ceará Fortaleza, Brazil

\begin{abstract}
:
Introduction: The growth of the older population is a worldwide phenomenon resulting from improvements in general living conditions and considerable advances in science and technology. Early retirement, which usually occurs with the aging process, is considered a phenomenon that causes great changes.
\end{abstract}

Objective: To relate the retirement process to subjective well-being in older people in the municipality of Fortaleza, Ceará, Northeastern Brazil.

Methods: Descriptive and analytical cross-sectional study conducted in Primary Healthcare Centers of the municipality of Fortaleza using questionnaires addressing sociodemographic data and the Sub-scale 2 of the Subjective Well-being Scale.

Results: Participants were 226 people aged 60-89 years, with a mean age of 69 years. Most of them were widowed $(95 ; 42 \%)$, retired $(159 ; 70.4 \%)$, had an income of up to two minimum wages $(193 ; 85.4 \%)$ and had up to five years of study $(125 ; 55.3 \%)$. Statistical significance $(p<0.05)$ was found between being/not being retired and the following variables: I like my life $(p=0.036)$, my life is bad $(p=0.017)$, I am dissatisfied with my life ( $p=0.032)$, I consider myself a happy person $(p=0.023)$.

Conclusion: The retirement process did not negatively influence the quality of life of the retirees. This could be evidenced by the positive answers to questions about general aspects of their lives, which revealed positive feelings about retirement.

Keywords: Aged; Retirement; Quality of life.

\section{INTRODUCTION}

The growth of the older population is a worldwide phenomenon resulting from improvements in general living conditions and considerable advances in science and technology. Statistics show that there were approximately 204 million older people in the world in 1950 and 579 million in 1998, and it is estimated that there will be two billion older people in 2050, accounting for $1 / 5$ of the world population - the majority living in developing countries. In Brazil, the 2010 Census had already recorded 20.6 million older people aged 60 and older, which is the age group targeted by the National Health Policy for Older People. The distribution of older people in the Brazilian regions reveal that $6.9 \%$ of older people are in the North region of the country, $8.8 \%$ in the Central-west region, $10.3 \%$ in the Northeast region, $11.8 \%$ in the Southeast region, and 12.0\% in the South region $[1,2,3]$.

With regard to older people, longevity is highlighted in Brazil by 24,5 thousand people over eighty years old. In the state of Ceará, the older population aged 60 or older increased from 658,900 people in 2000 to 1.063 million people in 2010, representing a 61\% increase in ten years [3].

Therefore, aging is a demographic reality in today's society with impact on health, quality of life and on the global economy, requiring sound policies and urgent actions to address the problem [4]. 
Undoubtedly, the work plays an important role in human existence as it is the main instigator of life organization [5]. For instance, job loss may become a risk factor for emotional and social imbalance and be a determinant of functional impairment, which can lead to the adoption of sedentary attitudes, substance abuse and poor eating habits [6].

In this perspective, the retirement, which usually occurs with the aging process, is considered a phenomenon that causes great changes. Studie in Brazil show that the poorly planned retirement is one of the determining factors for suicide among Brazilian older people [7].

There is evidence that diseases occurring before retirement may get worse after this event if the living conditions are inadequate [6], with drug addiction, depression, cardiorespiratory diseases, obesity and stress as the mostly reported problems [8]. For some people, the termination of employment, which is the main source of income, destabilizes the socioeconomic structure and affects retirees' standard of living [9]. Thus, the decrease in income becomes a major source of concern due to retirement. When people retire, they stop doing what, for a long period of time, represented financial gain and professional and personal fulfillment. Therefore, it is natural that moving into retirement generates expectations and becomes a threat to the standard of living [10].

Authors like Diener, Suh, Lucas and Smith [11] emphasize that the inclusion of subjective indicators is critical for assessing quality of life. However, the literature has shown that quality of life has long been assessed through economic and sociodemographic indicators, that is, objective indicators that can only depict the living conditions of individuals; the social indicators, including criteria for personal judgment of well-being and satisfaction with life, have just been incorporated into studies on quality of life [12].

In line with this thought, Marconcin [13] states that the assessment of quality of life implies not only the consideration of the objective well-being, that is, the living conditions of people, but also the subjective well-being, which is how people perceive the various areas of their life.

The subjective dimension of quality of life, also called subjective well-being (SWB), is expressed through emotional responses and satisfaction with life in specific domains such as leisure, health, finances, personal/emotional life and sense of belonging and also the overall satisfaction with present, past and future life. In other words, the subjective well-being refers to the reasons why personal experiences take place in a positive way, which is why it is based both on cognitive judgment and affective reactions resulting from these experiences $[12,13]$.

In this context, the present study aimed to assess the association between the retirement process and the subjective well-being in older people in the city of Fortaleza, Ceará, Northeastern Brazil.

\section{METHODS}

This is a descriptive and analytical cross-sectional study. The research sample consisted of older people attending Primary Healthcare Centers run by the Health Care System of the municipality of Fortaleza, Ceará, Northeastern Brazil. The centers provide health actions and services aimed at the maintenance of continuous, comprehensive and humanized care and also the promotion of clinical and health access, equity and effectiveness [14].

The sample comprised people aged 60 years and older according to the guidelines of the National Health Policy for Older People [3].

The sample size was determined to include 226 older people based on the number of older inhabitants in $2010(\mathrm{~N}=202,814)$ in the city of Fortaleza [15].

This minimum sample size was determined in order to estimate population proportion with an expected maximum sample size of $20 \%$, significance level of $5 \%$ (95\% confidence interval) and maximum permissible error of $5 \%$.

The following formula was used for the finite population:

$\mathrm{n}=\frac{\mathrm{N} \cdot \mathrm{k}^{2} \cdot \mathrm{p} \cdot \mathrm{q}}{\mathrm{e}^{2} \cdot(\mathrm{N}-1)+\mathrm{k}^{2} \cdot \mathrm{p} \cdot \mathrm{q}}$

Where: $\mathrm{n}=$ sample size; $\mathrm{N}=$ population; $\mathrm{k}=$ parameter corresponding to the level of significance; $\mathrm{p}=$ $\%$ occurrence; $\mathrm{q}=$ difference of $1-\mathrm{p} ; \mathrm{e}=$ sampling error. 
Data collection was performed by a single researcher who used a questionnaire addressing: a) sociodemographic data (age, marital status, gender, retirement, income and years of study); and b) the Subjective Well-being Sub-scale 2 (items 48-62).

The Subjective Well-being Scale is a scientific research method used in various areas of health [16]. This scale was validated in Brazil by Albuquerque and Tróccoli [17] and consists of components related to life satisfaction, positive affect and negative affect [18]. The assessment consists of a Likert-like psychometric scale of five points.

The items 48-62 (sub-scale 2) are intended to assess the satisfaction or dissatisfaction with life. It records the level of agreement or disagreement on a scale from 1 (strongly disagree) to 5 (strongly agree).

Inclusion criteria were: users of Primary Healthcare Centers aged 60 or older who did not present severe physical, cognitive, communication, sensory or mobility impairment that could prevent them from answering the questionnaires.

Participants were examined at home, health centers and social spaces frequented by them given their convenient locations.

Data were analyzed using the Statistical Package for the Social Sciences - SPSS version 20 (SPSS Co., Chicago, USA).

Statistical analysis was performed using inferential and chi-squared tests with a $95 \%$ confidence interval and a 5\% significance level. The results were statistically significant when $\mathrm{p}<0.05$.

Without any conflicts of interest, the project was approved by the Research Ethics Committee of the University of Fortaleza under Opinion No. 200/2009.

The present research is part of a larger study that is still in progress called "physical and mental performance tests as tools for the assessment and identification of older patients' oral health" funded by CNPq Process No. 478645 / 2013-9.

\section{RESUltS}

Participants were 226 older people aged 60-89 years, with a mean age of 69 years.

Table 1 shows that 95 (42\%) participants were widowed, 159 (70.4\%) reported being retired and 193 $(85.4 \%)$ reported an income of up to two minimum wages.

Regarding education, most participants $(\mathrm{n}=125 ; 55.3 \%)$ had up to five years of study.

Table1. Frequency distribution of older people according to sociodemographic aspects

\begin{tabular}{|l|c|c|}
\hline \multicolumn{1}{|c|}{ Variables } & Frequency & Percentage \\
\hline Marital Status & & 11.1 \\
\hline Single & 25 & 29.2 \\
\hline Married & 66 & 17.7 \\
\hline Divorced & 40 & 42 \\
\hline Widowed & 95 & 70.4 \\
\hline Retired & & 29.6 \\
\hline Yes & 159 & \\
\hline No & 67 & 85.4 \\
\hline Income & & 14.6 \\
\hline Up to 2 MW & 193 & \\
\hline More than 2 MW & 33 & 25.7 \\
\hline Years of Study & & 55.3 \\
\hline None & 58 & 10.2 \\
\hline Up to 5 years & 125 & 8.8 \\
\hline 6-9 years & 23 & \\
\hline 10 years or more & 20 & \\
\hline
\end{tabular}

Source: Research Data. $M W=$ Minimum wage $( \pm U S \$ 280)$

Table 2 shows the inferential analyses of the relationship between subjective well-being and retirement. Not all the respondents answered all the questions on the sub-scale 2 of the subjective well-being scale, which justifies any numerical differences listed in Table 2. 
Lia Pinheiro Freitas et al.

Of 159 retirees, $146(91.8 \%)$ reported being satisfied with life. In addition, $106(67.9 \%)$ retirees said that they leverage the opportunities of life, $123(82 \%)$ rated life positively, $90(60 \%)$ reported having achieved everything they set out to achieve in life, 104 (67.1\%) reported living a life in accordance with what they want for themselves, and 121 (81.2\%) do not consider their lives boring.

Statistical significance $(\mathrm{p}<0.05)$ was found between being retired and the following variables: I like my life ( $\mathrm{p}=0.036)$, my life is "not" bad ( $\mathrm{p}=0.017)$, I am "not" dissatisfied with my life ( $\mathrm{p}=0.032)$, and I consider myself a happy person ( $\mathrm{p}=0.023)$. Thus, the results showed that of all retirees, $155(98.1 \%)$ reported they like their lives, $148(93.7 \%)$ said that life is not bad, $144(91.7 \%)$ are not dissatisfied with life and, finally, 152 (96.8\%) considered themselves happy.

Table2. Association between retirement and subjective well-being (Subjective Well-being Scale Sub-scale 2)

\begin{tabular}{|c|c|c|c|c|}
\hline Variables & $\begin{array}{l}\text { Retired } \\
\mathbf{N}=159 \\
\mathbf{N}(\%)\end{array}$ & $\begin{array}{c}\text { Not retired } \\
\mathbf{N}=67 \\
\mathbf{N}(\%)\end{array}$ & $\begin{array}{c}\text { Prevalence } \\
\text { Ratio }\end{array}$ & p value* \\
\hline \multicolumn{5}{|c|}{ I am satisfied with my life } \\
\hline Yes & $146(91.8)$ & $62(92.5)$ & 1 & 0.856 \\
\hline No & $13(8.2)$ & $5(7.5)$ & $1.1(0.8-1.4)$ & \\
\hline \multicolumn{5}{|c|}{ I have leveraged the opportunities of life } \\
\hline Yes & $106(67.9)$ & $45(68.2)$ & $1(0.8-1.2)$ & 0.973 \\
\hline No & $50(32.1)$ & $21(31.8)$ & 1 & \\
\hline \multicolumn{5}{|c|}{ I rate my life in a positive way } \\
\hline Yes & $123(82.0)$ & $51(78.5)$ & $1.1(0.8-1.4)$ & 0.544 \\
\hline No & $27(18.0)$ & $14(21.5)$ & 1 & \\
\hline \multicolumn{5}{|c|}{ In most ways my life is far from my ideal } \\
\hline Yes & $51(33.8)$ & $18(27.3)$ & $1.1(0.9-1.3)$ & 0.344 \\
\hline No & $100(66.2)$ & $48(72.7)$ & 1 & \\
\hline \multicolumn{5}{|c|}{ I would change my past if I could } \\
\hline Yes & $86(55.5)$ & $36(58.1)$ & 1 & 0.729 \\
\hline No & $69(44.5)$ & $26(41.9)$ & $1(0.9-1.2)$ & \\
\hline \multicolumn{5}{|c|}{ I have achieved everything I set out to achieve in life } \\
\hline Yes & $90(60.0)$ & $38(59.4)$ & $1(0.8-1.2)$ & 0.932 \\
\hline No & $60(40.0)$ & $26(40.6)$ & 1 & \\
\hline \multicolumn{5}{|c|}{ I live my life in accordance with what I want for myself } \\
\hline Yes & $104(67.1)$ & $42(66.7)$ & $1(0.8-1.2)$ & 0.951 \\
\hline No & $51(32.9)$ & $21(33.3)$ & 1 & \\
\hline \multicolumn{5}{|l|}{ I like my life } \\
\hline Yes & $155(98.1)$ & $62(92.5)$ & $1.9(0.8-4.7)$ & $\mathbf{0 . 0 3 9}$ \\
\hline No & $3(1.9)$ & $5(7.5)$ & 1 & \\
\hline \multicolumn{5}{|l|}{ My life is bad } \\
\hline Yes & $10(6.3)$ & $11(16.4)$ & 1 & 0.017 \\
\hline No & $148(93.7)$ & $56(83.6)$ & $1.5(1-2.4)$ & \\
\hline \multicolumn{5}{|c|}{ I am dissatisfied with my life } \\
\hline Yes & $13(8.3)$ & $12(18.2)$ & 1 & $\mathbf{0 . 0 3 2}$ \\
\hline No & $144(91.7)$ & $54(81.8)$ & $1.4(1-2.1)$ & \\
\hline \multicolumn{5}{|c|}{ My life could be better } \\
\hline Yes & $132(85.7)$ & $59(88.1)$ & 1 & 0.640 \\
\hline No & $22(14.3)$ & $8(11.9)$ & $1.1(0.8-1.3)$ & \\
\hline \multicolumn{5}{|c|}{ I have more moments of sadness than hapiness in my life } \\
\hline Yes & $29(20)$ & $15(24.6)$ & 1 & 0.463 \\
\hline No & $116(80)$ & $46(75.4)$ & $1(0.8-1.3)$ & \\
\hline \multicolumn{5}{|l|}{ My life is boring } \\
\hline Yes & $28(18.8)$ & $20(30.3)$ & 1 & 0.062 \\
\hline No & $121(81.2)$ & 46 (69.7) & $1.2(1-1.6)$ & \\
\hline \multicolumn{5}{|c|}{ I consider myself a happy person } \\
\hline Yes & $152(96.8)$ & $58(89.2)$ & $1.7(0.9-3.4)$ & 0.023 \\
\hline No & $5(3.2)$ & $7(10.8)$ & 1 & \\
\hline
\end{tabular}

Source: Research Data. *Chi-square test. 


\section{DISCUSSION}

The present research stands out for shedding light on the fact that retirement causes social and psychological problems in older people.

Daily work has always been regarded as a social space for sharing, financial independence and a form of occupation for both the body and the mind. Regarding this issue, Caldas [19] says that retirement can be considered the end of a phase of life. However, keeping busy and carrying out activities during this new phase can bring benefits to the retired person.

Although previous studies such as the one by Bossé et al.[20] have not found differences in psychological symptoms between retirees and workers, others have reported improved mental health and emotional aspects in retirees who held some kind of occupation after retirement [21] and a worsening in mental health in inactive retirees [22]. The general analysis of data in the present research revealed a strong presence of positive aspects of being retired reported by the respondents. According to Kim and Moen [6], retirement can promote a sense of well-being in workers moving out of demanding and stressful work environments. In contradiction to this perception, a study by Magalhães et al.[23] states that the retirement process can be experienced as a rupture imposed by the outside world, leading to frustration and feeling of emptiness, since the work was strongly associated with identity. Therefore, it should be noted that when retirement is assimilated in a negative way, it can cause problems in one's psychic structure.

Respondents revealed optimistic reactions regarding "satisfaction with life" and "leverage of the opportunities of life", demonstrating emotional balance when dealing with retirement. Accordingly, Soares et al. [24] highlight the importance of finding other forms of satisfaction with retirement by replacing rewarding stimuli deriving from professional identity for new ways of seeking pleasure. The author states that this new phase of life can be as rewarding as the experiences in previous phases as long as it enables personal development, preserving self-esteem and changing the idea that satisfaction can only be obtained through work activities.

According to Alvarenga et al. [25], there are many ways in which older people can remain active after retirement and there is a great concern regarding the formulation of public and social policies to promote healthy aging. The alternatives to achieve this type of aging are those that encourage older people to engage in volunteer work and be proactive, encouraging them to set goals and work out to reach them, keeping them actively involved in the preservation of their well-being.

When asked about their positive rating of life and if they "achieved everything they set out to achieve in life" and if they "live their lives according to what they want for themselves", the older people were assertive in their responses, demonstrating the bright side retiring.

With regard to satisfaction during the retirement period, Delgado [26] points out that this phase fosters reflections about being old and about the feelings regarding the body and the place of the older person in society. Such reflections can be either positive or negative depending on the investments made by the worker who is about to retire. Moving into a satisfactory retirement does not only depend on holding pleasurable activities or having an income consistent with one own's needs or having free time; it is mostly about having a personal knowledge of the body, the limits to be established and the needs to be fulfilled, i.e., a self-knowledge to achieve a better adaptation to this new phase of life.

When asked if they considered life boring, most respondents answered no. This appears as another positive point and a key factor to a satisfactory retirement. In this sense, retirement may save time and reduce stress related to the worker's role. Consequently, when men retire, their moral or general life satisfaction seems to increase [6]. In line with this thought, Santo, Góes and Chibante [27] report that, although less frequently, other positive points have also been evidenced by older people. Factors such as the sense of accomplishment, regular income upon retirement, being able to enjoy time with family and meeting a new world were highlighted as pleasurable aspects of a new experienced stage.

With regard to the question "Do you like your life?", most respondents answered yes, revealing that the retirement process is not experienced negatively and does not cause any apparent psychological distress.

Thus, the reflection about aging and moving into retirement reveals that this phase of life can be experienced in a positive way, with gains in the development of physical, social, cognitive and psychological capabilities. These factors may be directly associated with positive health outcomes in older people - for instance, the increased longevity and the adoption of healthy behaviors [28]. 
The positive answers regarding satisfaction with life and the number of respondents who said life is not bad and who considered themselves happy confirm that retirement does not necessarily need to be seen as an unpleasant factor in the lives of older people or be synonymous with disease. In this context, this phase transition can establish a positive and beneficial relationship between the older person and the family and social circle and also improve self-esteem with the return to old projects, which lead to a positive quality of life.

However, the study by Santo, Góes and Chibante [27] contradicts this statement when they say that great "villains" are faced by older people during retirement. They report that the low payment during retirement has been highlighted as a major frustration by older people as they have enough time to perform pleasurable activities but do not receive enough money to do so. The need for reentering the labor market in order to supplement the family income - and not only for pleasure - appeared as a major fear that has become a significant issue to be discussed.

Faced with the facts, it is essential to know the real idea older people have of retirement in order to organize the care provided to these people and promote the maintenance of their autonomy and independence for a healthier life.

Further studies should be carried out in order to know the feelings and perceptions of retirees and provide them with improved quality of life.

\section{Conclusion}

Although most retirees in the present research had low income and education, it was possible to identify that the retirement process does not negatively influence quality of life, a fact that has been evidenced by respondents' positive feelings about retirement.

Consequently, a good quality of life was highlighted through affirmative answers regarding happiness and satisfaction with life, revealing that the retirement process did not affect the physical and mental health of most respondents.

\section{REFERENCES}

[1] OMS - Organização Mundial da Saúde. Financiamento dos Sistemas de Saúde. Brasília: Organização Pan-Americana da Saúde, 2010.

[2] Instituto Brasileiro de Geografia e Estatística. Apresenta estatística sobre a população. IBGE, 2013. Disponível em: http://www.ibge.gov.br

[3] Brasil. Portaria nº 2528 de 19 de outubro de 2006. Aprova a Política Nacional de Saúde da Pessoa Idosa. Diário Oficial da União. Brasília, 2006.

[4] Wong RLR, Carvalho JAM, Perpétuo IHO. A estrutura da população brasileira no curto e médio prazos: evidências sobre o panorama demográfico com referência às políticas sociais, particularmente as de saúde. Rede Interagencial de Informações para Saúde, Brasília, 2009.

[5] Zanelli V. Influências da aposentadoria na identidade pessoal. Santa Catariana [Graduação em Psicologia]. - Universidade do Sul de Santa Catarina 2007; 58 p.

[6] Kim J, Moen P. Retirement transitions, Gender, and Psychological Well-Being: A Life-Course, Ecological model. J Gerontol: psychological Science 2002; 57 (3):212-222.

[7] Minayo MCS, Cavalcante FG, Mangas RMN, Souza JRA. Autópsias psicológicas sobre suicídio de idosos no Rio de Janeiro. Ciência e Saúde coletiva 2012; 17 (10):2773-2781.

[8] Nimrod G. Time for old friends and grandchildren? Post-Retirement Get-Togethers and Life satisfactions. J Can Ass Leisure Studies 2008; 32 (1):21.

[9] Néri MC. Renda, consumo e aposentadoria: evidências, atitudes e percepções. Ensaios Econômicos 2007; 663:1-27.

[10] Cintra TS, Ribeiro DF. O mundo do trabalho e o processo de envelhecimento: o cotidiano e as representações de aposentados. In: Anais do Anais do 3. Congresso Internacional de psicologia e 9. Semana de Psicologia 2007; BRASIL.

[11] Diener E, Suh EM, Lucas RE, Smith HL. Subjective well- being: Three decades of progress. Psychological Bulletin 1999; 125:276-302.

[12] Cardoso MCS, Ferreira MC. Envolvimento religioso e bem-estar subjetivo em idosos. Psicol. cienc. prof. 2009; 29 (2):380-393. 
[13] Marconcin PEP et al. Bem-estar subjetivo e a prática de atividade desportiva em idosos alunos de universidades seniores do Porto. RBCEH 2010; 7 (3):335-345.

[14] Brasil. Ministério da Saúde. Política Nacional de Atenção Básica. Série E. Legislação em Saúde. Brasília, 2012.

[15] Brasil/Datasus. Ministério da Saúde. População residente no Estado do Ceará. DATASUS, 2010. Available from: http://tabnet.datasus.gov.br/cgi/tabcgi.exe?ibge/cnv/popce.def. Acessed: 22 july 2016.

[16] Diener E, Chan MY. Happy People Live Longer: Subjective Well-Being Contributes to Health and Longevity. Applied Psychology: health and well-being 2011; 3:1-43.

[17] Albuquerque AS, Tróccoli BT. Desenvolvimento de Uma Escala de Bem-Estar Subjetivo. Psicologia: Teoria e Pesquisa 2004; 20 (2): 153-164.

[18] Andrews FM, Withey SB. Developing measures of perceived life quality: results from several national surveys. Social Indicators Research 1974; 1:1-26.

[19] Caldas CP. Preparação para uma aposentadoria ativa. In: Júnior JCB. (Org.). Empreendedorismo, Trabalho e Qualidade de Vida na Terceira Idade 2009; 141-151.

[20] Bossé R, Aldwin C, Levenson M, Ekerdt D. Mental health diferences among retirees and workers: findings from the Normative Aging Study. Psychol Aging 1987; 2:383-389.

[21] Reitzes DC, Mutran EJ, Fernandes ME. Does retirement hurt well-being? Factors influencing self-steem and depression among retirees and workers. Gerontologist 1996; 36:649-656.

[22] Gonzáles FAL, Mota VG, Salas-ro-mero MF. Depression em jubilados no activos. Estudio de 234 casos. Rev Med 1995; 33:51-55.

[23] Magalhães MO, Krieger DV, Vivian AG, Straliotto MCS, Poeta MP. Padrões de ajustamento na aposentadoria. Aletheia 2004; 1 (19).

[24] Soares DHP, Costa AB, Rosa AM, Oliveira MLS. Aposenta-ação: programa de preparação para aposentadoria. Estudos Interdisciplinares do Envelhecimento 2007; 12:143-161.

[25] Alvarenga LN, Kiyan L. Bitencourt B, Wanderley KS. The impact of retirement on the quality of life of the elderly. Rev Esc Enferm USP 2009; 43 (4):794-800.

[26] Delgado J. Velhice, corpo e narrativa. Porto Alegre (RS): Horizontes Antropológicos 2010; 34:189-212.

[27] Santo FHE, Góes PMF, Chibante CLP. Limites e possibilidades do idoso frente à aposentadoria. Revista Kairós Gerontologia 2014; 17 (4):323-335.

[28] Sargnet-Cox KA, Butterworth P, Anstey KJ. Role of physical activity in the relationship between mastery and functional health. Gerontologist 2015; 55 (1):120-131. 